\title{
Analisis Teori Perkembangan Kognitif Jean Piaget dan Implikasinya bagi Pembelajaran
}

\author{
Alon Mandimpu Nainggolan ${ }^{1)}$, Adventrianis Daeli ${ }^{2)}$ \\ Institut Agama Kristen Negeri Manado; Praktisi Pendidikan \\ nainggolanalon1008@gmail.com
}

\begin{abstract}
Abstrak
Penelitian ini bertujuan untuk mendeskripsikan teori perkembangan kognitif Jean Piaget dan bagaimana implikasinya bagi pembelajaran di lingkungan Pendidikan Kristen. Untuk mewujudkan tujuan penelitian tersebut, maka penulis memilih metode kualitatif dengan analisis deskriptif. Sumber primer dan sekunder mengenai teori perkembangan kognitif Jean Piaget dimanfaatkan untuk membangun konsep pembelajaran yang berdampak positif terhadap anak. Melalui penelitian ini ditemukan bahwa teori perkembangan kognitif Jean Piaget perlu ditinjau dari perspektif Kristen agar relevan dan dapat diterapkan dalam pembelajaran bagi anak di lingkungan pendidikan Kristen. Dalam teorinya, ada empat periode utama perkembangan kognitif manusia, perkembangan kognitif seseorang dimulai dari berpikir konkrit sampai berpikir secara abstrak. Piaget sangat menekankan bahwa seorang anak harus diajar sesuai dengan tahap perkembangan kognitifnya. Cara berpikir anak berbeda dengan cara berpikir orang dewasa.
\end{abstract}

Kata kunci: Jean Piaget; kognitif; perkembangan; Pendidikan Kristen.

\section{Pendahuluan}

Sejatinya ada banyak tokoh psikologi yang telah memberikan sumbangsih pemikirannya kepada dunia pendidikan, namun pada kesempatan ini penulis tertarik untuk mengkaji hidup dan karya seorang tokoh psikologi penting di abad ke-20 yang berasal dari Negara Swis yaitu Jean Piaget (Naisaban, 2006:324). Gagasannya yang cukup dikenal oleh banyak orang di seluruh penjuru dunia adalah mengenai perkembangan kognitif manusia yang melalui empat tahap (Santrock, 2012). Kontribusi pemikirannya bagi praktik pendidikan terhadap anak tidak terbantahkan oleh siapapun dan kapanpun. Itu sebabnya, penulis ingin mengkaji pemikiran dari Jean Piaget karena diyakini bahwa teorinya dapat dipergunakan atau diimplementasikan ke dalam dunia pendidikan, secara khusus konteks Pendidikan Kristen bagi anak sehingga pembelajaran dapat berlangsung efektif dan efisien.

Teori Piaget mengenai perkembangan kognitif memberikan batasan kembali mengenai kecerdasan, pengetahuan dan relasi anak didik dengan lingkungannya. Kecerdasan merupakan proses berkesinambungan membentuk struktur yang diperlukan dalam interaksi berkelanjutan dengan lingkungan. Struktur yang dibentuk oleh kecerdasan, pengetahuan sangat subjektif waktu masih bayi dan masa kanak-kanak awal dan menjadi objektif dalam masa dewasa awal. Perkembangan cara berfikir dari masa bayi sampai usia dewasa meliputi 
masa sensorimotor (0-2 tahun), anak mengalami dunianya melalui gerak dan inderanya serta mempelajari permanensi objek; pra operasi (2-6 tahun), anak memulai kecakapan motorik; operasi konkrit (7-12 tahun), anak mulai berpikir secara logis; dan operasi formal (13-17 tahun), adanya penalaran abstrak (Feldmeier, 2007: 40). Proses dibentuknya setiap struktur yang lebih kompleks ini adalah asimilasi dan akomodasi, yang diatur oleh ekuilibrasi.

Piaget telah memberi suatu kerangka konseptual yang berkualitas untuk melihat masalah-masalah seputar pendidikan, yang di dalamnya pembelajaran (Ichsan, 2009:1). Maka, yang menjadi pertanyaan penelitian dalam artikel ini adalah apa implikasi teori perkembangan kognitif Piaget bagi pembelajaran anak di lingkungan Pendidikan Kristen di masa kini dan mendatang? Melalui penelitian ini penulis hendak mendeskripsikan persepsi Piaget mengenai perkembangan kognitif dan bagaimana konsep itu bermanfaat bagi efektifitas dan efisiensi pembelajaran yang dikelola oleh seorang guru terhadap peserta didiknya. Dalam konteks Pendidikan Kristen, diyakini bahwa jika teori perkembangan kognitif Piaget dianalisis, dievaluasi dan dikontekstualisasikan berdasarkan Alkitab, maka akan mempengaruhi keberhasilan seorang guru dalam pembelajarannya terhadap peserta didiknya.

\section{Metode Penelitian}

Metode penelitian yang digunakan oleh penulis adalah metode kualitatif dengan pendekatan analisis deskriptif. Bertolak dari pandangan bahwa fokus penelitian adalah kualitas makna (hakikat dan esensi). Secara holistik dan dengan cara deskripsi dalam bentuk kata-kata dan bahasa (Moleong, 2011: 6). Pola pikir dalam penelitian kualitatif adalah pola pikir induktif. Pola pikir induktif merupakan suatu cara berpikir dengan mendasarkan pada pengalaman-pengalaman yang diulang-ulang, atau suatu cara, atau jalan yang dipakai untuk mendapatkan ilmu pengetahuan dengan bertitik tolak dari pengamatan atas hal-hal atau masalah yang bersifat khusus, kemudian menarik pada kesimpulan yang bersifat umum.

Penulis memilih, menetapkan sumber primer dan sekunder (buku, jurnal, website, dan lain-lain) sebagai sumber data penelitian. Setelah data terkumpul mengenai hidup dan karya Piaget, maka penulis melakukan analisis data. Penulis menganalisis dengan cara melihat dan mencocokkan kesesuaian, kesamaan, keterkaitan, ketepatan data dengan judul penelitian (nainggolan, 2020: 13-25). Setelah penulis menganalisis data, maka akan dilanjutkan dengan pembahasan dan pemaparan kesimpulan. 


\section{Hasil Dan Diskusi}

\section{Biografi Jean Piaget}

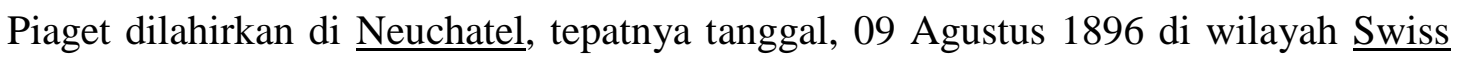
yang berbahasa Perancis. Ayahnya, Arthur Piaget, adalah seorang profesor dalam sastra Abad Pertengahan di Universitas Neuchatel. Piaget adalah seorang anak yang terlalu cepat menjadi matang, yang mengembangkan minatnya dalam Biologi (ahli Biologi) dan dunia pengetahuan alam, khususnya tentang moluska / kerang-kerangan (Paul Suparno, 2006:11). Pada umur 10 tahun (1907) ia sudah dapat menulis suatu jurnal ilmiah Biologi di Journal of Natural History of Neuchatel. Pada usia 11 tahun, ia kembali menerbitkan sebuah makalah

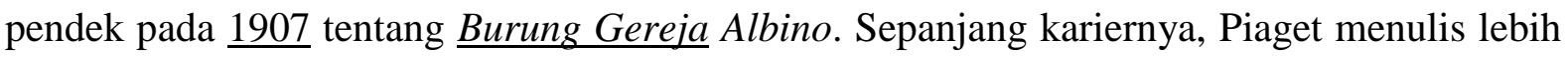
dari 60 buah buku dan ratusan artikel (Boeree, 2007:479).

Pada usia yang masih sangat muda, yakni 21 tahun ia sudah menyandang gelar Doktor Natural Science (Paul Suparno, 2006:12). Piaget memperoleh gelar Ph.D. dalam ilmu alamiah dari Universitas Neuchatel, dan juga belajar sebentar di Universitas Zurich. Selama masa ini, ia menerbitkan dua makalah filsafat yang memperlihatkan arah pemikirannya pada saat itu, namun yang belakangan ditolaknya karena dianggapnya sebagai karya tulis seorang remaja. Minatnya terhadap psikoanalisis, sebuah aliran pemikiran psikologi yang berkembang pada saat itu, juga dapat dicatat mulai muncul pada periode ini. Dari Biologi akhirnya ia tertarik kepada Filsafat, lalu Psikologi (Freud \& Jung).

Belakangan ia pindah dari Swiss ke Grange-aux-Belles, Perancis, dan di sana ia mengajar di sekolah untuk anak-anak lelaki yang dikelola oleh $\underline{\text { Alfred Binet, pengembang tes }}$ intelegensia Binet. Ketika ia menolong menandai beberapa contoh dari tes-tes intelegensia inilah Piaget memperhatikan bahwa anak-anak kecil terus-menerus memberikan jawaban yang salah untuk pertanyaan-pertanyaan tertentu. Piaget tidak terlalu memperhatikan pada jawaban-jawaban yang keliru itu, melainkan pada kenyataan bahwa anak-anak yang kecil itu terus-menerus membuat kesalahan dalam pola yang sama, yang tidak dilakukan oleh anakanak yang lebih besar dan orang dewasa. Hal ini menyebabkan Piaget mengajukan teori bahwa pemikiran atau proses kognitif anak-anak yang lebih kecil pada dasarnya berbeda dengan orang-orang dewasa. Pada 1921, Piaget kembali ke Swiss sebagai direktur Institut Rousseau di Geneva.

Pada 1923, ia menikah dengan salah seorang rekan kerja mahasiswa, Valentine Chatenay. Pada tahun 1925, putri pertama mereka lahir, pada tahun 1927, putri kedua mereka lahir, dan pada tahun 1931, satu-satunya anak laki-laki lahir. Mereka segera menjadi fokus pengamatan intensif oleh Piaget dan istrinya. Dalam perjalanan karirnya dibantu istrinya, ia 
mengamati perkembangan tiga anaknya. Pada $\underline{1929}$, Jean Piaget menerima jabatan sebagai Direktur Biro Pendidikan Internasional, yang tetap dipegangnya hingga 1968. Setiap tahun, ia menyusun "Pidato Direkturnya" untuk Dewan BPI itu dan untuk Konferensi Internasional tentang Pendidikan Umum, dan di dalamnya ia secara eksplisit mengungkapkan keyakinan pendidikannya. Jean Piaget meninggal pada tanggal 16 September 1980 di Jenewa, Swiss pada usia 84 tahun (Naisaban, 2006:324). Sekarang Ia adalah tokoh besar abadi dalam Psikologi Perkembangan, khususnya perkembangan kognitif. Tertarik pada perubahanperubahan kualitatif perkembangan mental anak sampai dewasa.

\section{Konsep Psikologinya}

Menurut Piaget, perkembangan kognitif mempunyai empat aspek dasar / konsep dasar, yaitu (Gunarsa, 2006: 141);

1. Kematangan / kemasakan, sebagai hasil perkembangan susunan syaraf. Kematangan ini merupakan pengembangan dari susunan syaraf. Contohnya, kemampuan melihat atau mendengar disebabkan oleh kematangan yang sudah dicapai oleh susunan syaraf yang bersangkutan.

2. Pengalaman, yaitu relasi timbal balik antara organisme dengan dunianya. Relasi timbal balik antara organisme dengan lingkungannya.

3. Interaksi / transmisi sosial, yaitu pengaruh-pengaruh yang diperoleh dalam relasinya dengan lingkungan sosial. Seseorang bertumbuh sebagaimana ia berinteraksi dengan lingkungan / sesama. Contohnya, cara pengasuhan dan pendidikan dari orang lain yang diberikan kepada anak. Melalui dua proses yaitu organisasi dan adaptasi.

4. Ekuilibrasi, yaitu adanya kemampuan atau sistem mengatur dalam diri organisme agar dia selalu mampu mempertahankan keseimbangan dan beradaptasi terhadap lingkungannya. Piaget mengemukakan bahwa setiap organisme yang mau mengadakan adaptasi dengan lingkungannya, harus mencapai keseimbangan yaitu antara aktivitas organisme terhadap lingkungan dan sebaliknya. Agar terjadi ekuilibrasi antara dirinya dengan lingkungan, maka peristiwa-peristiwa asimilasi dan akomodasi harus terjadi secara terpadu, bersama-sama dan komplementer.

Piaget melihat kemampuan anak memperlihatkan pola teratur dalam geraknya (skema). Piaget juga mengamati bahwa anak membangun kemampuan kognitif adaptasi (menyesuaikan diri) dengan lingkungannya. Lebih jelasnya ada dua sistem yang mengatur dari dalam mempunyai dua faktor, diantaranya: Pertama, skema berhubungan dengan pola 
tingkah laku yang teratur yang diperhatikan oleh organisme yang merupakan akumulasi dari tingkah laku yang sederhana hingga yang kompleks. Misalnya, skema: dunia raih, hisap, merangkak, mengenyot pipi, melihat, dan lain-lain. Kedua, adaptasi adalah fungsi penyesuaian terhadap lingkungan yang terdiri atas proses asimilasi dan akomodasi.

Adaptasi dibagi ke dalam dua proses yang saling mengisi, diantaranya;

Pertama, asimilasi. Asimilasi adalah kecenderungan organisme untuk mengubah lingkungannya (objek) guna menyesuaikan diri dengan dirinya sendiri atau organisme memanipulasi dunia luar dengan cara membuatnya menjadi serupa dengan dirinya. Asimilasi mengambil sesuatu dari dunia luar dan mencocokkannya ke dalam struktur yang telah ada (Sanjaya, 2010:132). Misalnya, manusia mengasimilasi makanan dengan membuatnya ke dalam komponen nutrisi, makanan yg mereka makan menjadi bagian dari diri mereka. Dengan kata lain, asimilasi adalah kemampuan anak mengubah objek yang dilihat dan disentuh sesuai dengan pola pikirnya.

Kedua, akomodasi. Akomodasi adalah kecenderungan organisme (subjek) untuk mengubah dirinya sendiri guna menyesuaikan diri dengan lingkungan atau organisme memodifikasi dirinya sehingga menjadi lebih menyukai lingkungannya (Surya, 2003:56). Ketika seseorang mengakomodasi sesuatu, mereka mengubah diri mereka sendiri untuk memenuhi kebutuhan eksternal. Contohnya, tubuh tidak hanya mengasimilasi makanan namun juga mengakomodasikannya dengan mensekresi cairan lambung untuk menghancurkannya dan kontraksi lambung mencernanya secara involunter. Kemampuan anak sebagai subjek menyesuaikan diri terhadap objek di luar dirinya.

Melalui kedua proses penyesuaian tersebut, sistem kognisi seseorang berubah dan berkembang sehingga bisa meningkat dari satu tahap ke tahap di atasnya. Proses penyesuaian tersebut dilakukan seorang individu karena ia ingin mencapai keadaan equilibrium (keseimbangan), yaitu berupa keadaan seimbang antara struktur kognisinya dengan pengalamannya di lingkungan. Seseorang akan selalu berupaya agar keadaan seimbang tersebut selalu tercapai dengan menggunakan kedua proses penyesuaian di atas. Dengan demikian, kognisi seseorang berkembang bukan karena menerima pengetahuan dari luar secara pasif namun orang tersebut secara aktif mengkonstruksi pengetahuannya. Hubungan antara asimilasi dan akomodasi adalah komplementer. Dalam setiap tingkah laku organisme dapat ditemukan aspek asimilasi dan akomodasi. Dalam konteks ini penting untuk berupaya memelihara keseimbangan asimilasi dengan akomodasi. 


\section{Tahap-Tahap Perkembangan Kognitif}

Jean Piaget membagi ke dalam empat tahapan perkembangan kognitif anak. Ia mengemukakan bahwa kemampuan berpikir atau kekuatan mental anak-anak berbeda pada masing-masing tahapan. Bagi Piaget anak akan berkembang secara kognitif dengan sehat dipengaruhi oleh potensi yang ada dalam dirinya dan pengalaman yang diperoleh dari lingkungan sekitarnya. Dalam hal ini guru berperan sebagai fasilitator dan motivator agar anak berkembang sesuai tahapannya dengan menambahkan pengalaman yang meningkatkan potensinya secara optimal.

Skema Empat Tingkatan perkembangan Kognitif Piaget (Suparno, 2011: 25)

\begin{tabular}{|c|c|c|}
\hline Tahap & Umur & Ciri Pokok Perkembangan \\
\hline Sensorimotor & $0-2$ tahun & $\begin{array}{l}\text { - } \text { Berdasarkan tindakan } \\
\text { - } \quad \text { Langkah demi langkah }\end{array}$ \\
\hline Praoperasi & 2-7 tahun & - Penggunaan simbol / bahasa tanda \\
\hline Operasi Konkret & $8-11$ tahun & $\begin{array}{l}\text { - Pakai aturan jelas / logis } \\
\text { - Reversibel dan kekekalan }\end{array}$ \\
\hline Operasi Formal & 11 tahun ke atas & $\begin{array}{ll}\text { - } & \text { Hipotesis } \\
\text { - } & \text { Abstrak } \\
\text { - } & \text { Deduktif dan Induktif } \\
\text { - } & \text { Logis dan Probabilitas }\end{array}$ \\
\hline
\end{tabular}

Hal senada dikemukakan oleh Santrock bahwa Jean Piaget membagi perkembangan kognitif anak ke dalam empat periode utama yang berkorelasi dengan dan semakin canggih seiring pertambahan usia, diantaranya (Santrock, 2012);

\section{Tahap Sensorimotor (0-2 tahun)}

1. Aktivitas kognitif berpusat pada aspek alat indera / sensori) dan gerak / motor (Diane, et.all, 2008:212; Surya, 2003:57).

2. Kemampuan yang dimiliki antara lain:

a. Suka dan cenderung memerhatikan sesuatu lebih lama;

b. Melihat dirinya sendiri sebagai mahkluk yang berbeda dari objek di sekitarnya;

c. Mendefinisikan sesuatu dengan memanipulasinya;

d. Mencari rangsangan melalui sinar lampu dan suara, dan lain-lain. 
Piaget berpendapat bahwa tahapan ini menandai perkembangan kemampuan dan pemahaman spatial penting dalam enam sub-tahapan:

1. Sub-tahapan skema refleks, muncul saat lahir sampai usia enam minggu dan berhubungan terutama dengan refleks.

2. Sub-tahapan fase reaksi sirkular primer, dari usia enam minggu sampai empat bulan dan berhubungan terutama dengan munculnya kebiasaan-kebiasaan.

3. Sub-tahapan fase reaksi sirkular sekunder, muncul antara usia empat sampai sembilan bulan dan berhubungan terutama dengan koordinasi antara penglihatan dan pemaknaan.

4. Sub-tahapan koordinasi reaksi sirkular sekunder, muncul dari usia sembilan sampai dua belas bulan, saat berkembangnya kemampuan untuk melihat objek sebagai sesuatu yang permanen walau kelihatannya berbeda kalau dilihat dari sudut berbeda (permanensi objek).

5. Sub-tahapan fase reaksi sirkular tersier, muncul dalam usia dua belas sampai delapan belas bulan dan berhubungan terutama dengan penemuan cara-cara baru untuk mencapai tujuan.

6. Sub-tahapan awal representasi simbolik, berhubungan terutama dengan tahapan awal kreativitas.

Secara sederhana dapat dikemukakan bahwa perkembangan skema melalui refleks untuk membangun dunianya. Kemampuan bahasa; pemusatan (centrasi); klasifikasi tunggal; permanensi objek. Usia 2 tahun anak mulai berpikir.

\section{Tahap Preoperasional (umur 2-7/8 tahun)}

1. Memahami realitas dengan menggunakan tanda-tanda dan simbol.

2. Cara berfikirnya tidak bersifat sistematis, tidak konsisten, dan tidak logis.

3. Cara berfikir anak pada tingkat ini yaitu: yang pertama, Tranductive reasioning: Cara berpikir yang bukan induktif dan deduktif tetapi tidak logis. Yang kedua, ketidakjelasan hubungan sebab akibat : Anak mengenal hubungan sebab akibat secara logis. Yang ketiga, animism : Menganggap bahwa semua benda itu hidup seperti dirinya. Yang keempat, artificalism : Kepercayaan bahwa segala sesuatu di lingkungan itu mempunyai jiwa sama seperti manusia. Yang kelima, perceptually bound : Anak menilai sesuatu berdasarkan apa yang ia lihat dan ia dengar. Yang keenam, mental experiment : Anak mencoba melakukan sesuatu untuk menemukan jawaban dari persoalan yang dihadapinya. Yang ketujuh, centration : Anak memusatkan perhatiannya kepada sesuatu ciri yang paling menarik dan mengabaikan 
ciri yang lainnya. Yang kedelapan, egocentrism : Anak melihat dunia lingkungannya menurut kehendaknya sendiri (Surya, 2003:57-58).

Secara sederhana di rentang usia ini anak sedang egosentris; penggunaan simbol dan penyusunan tanggapan internal: permainan, bahasa, peniruan. Mereka mampu menyusun, mengelompokkan dan konservasi. Pemikiran pada anak pra operasional sangat didasarkan pada hal-hal yang konkrit belaka dan belum memahami prinsip pembolak-balikan serta sangat mementingkan ide dari perspektifnya sendiri, intinya anak masih kurang mampu berpikir secara abstrak (Philips, 1969:58).

\section{Tahap Operasional Konkrit (Umur 7 atau 8-11 atau 12 tahun)}

1. Pengurutan, artinya kemampuan untuk mengurutkan objek menurut ukuran, bentuk, atau ciri lainnya. Misalnya, bila diberi benda berbeda ukuran, mereka dapat mengurutkannya dari benda yang paling besar ke yang paling kecil.

2. Klasifikasi, artinya kemampuan untuk memberi nama dan mengidentifikasi serangkaian benda menurut tampilannya, ukurannya, atau karakteristik lain, termasuk gagasan bahwa serangkaian benda-benda dapat menyertakan benda lainnya ke dalam rangkaian tersebut. Anak tidak lagi memiliki keterbatasan logika berupa animisme (anggapan bahwa semua benda hidup dan berperasaan).

3. Decentering, artinya anak mulai mempertimbangkan beberapa aspek dari suatu permasalahan untuk bisa memecahkannya. Sebagai contoh anak tidak akan lagi menganggap cangkir lebar namun pendek lebih sedikit isinya dibanding cangkir kecil yang tinggi.

4. Reversibility, artinya anak mulai memahami bahwa jumlah atau benda-benda dapat diubah, kemudian kembali ke keadaan awal. Untuk itu, anak dapat dengan cepat menentukan bahwa 4+4 sama dengan 8, 8-4 akan sama dengan 4, jumlah sebelumnya.

5. Konservasi, artinya memahami bahwa kuantitas, panjang, atau jumlah benda-benda adalah tidak berhubungan dengan pengaturan atau tampilan dari objek atau bendabenda tersebut. Sebagai contoh, bila anak diberi cangkir yang seukuran dan isinya sama banyak, mereka akan tahu bila air dituangkan ke gelas lain yang ukurannya berbeda, air di gelas itu akan tetap sama banyak dengan isi cangkir lain.

6. Penghilangan sifat egosentrisme, artinya kemampuan untuk melihat sesuatu dari sudut pandang orang lain (bahkan saat orang tersebut berpikir dengan cara yang salah). Sebagai contoh, tunjukkan komik yang memperlihatkan Alon menyimpan Smartphone di dalam kotak, lalu meninggalkan ruangan, kemudian Aurora memindahkan Smartphone itu ke dalam laci, setelah itu baru Alon kembali ke 
ruangan. Anak dalam tahap operasi konkrit akan mengatakan bahwa Alon akan tetap menganggap Smartphone itu ada di dalam kotak walau anak itu tahu bahwa Smartphone itu sudah dipindahkan ke dalam laci oleh Aurora.

7. Anak mulai berpikir secara logis tentang kejadian-kejadian konkret (Jarvis, 2011:149$150)$.

8. Mencapai kemampuan untuk berpikir sistematis terhadap hal-hal atau obyek-obyek yang konkrit.

9. Self counternya sangat menonjol.

10. Anak sudah mulai menggunakan aturan-aturan yang jelas dan logis, dan lain-lain.

Secara sederhana dalam usia ini, anak sedang mencapai kemampuan berpikir sistematik terhadap objek konkrit; kemampuan konservasi. Mereka telah memiliki kemampuan negasi, kemampuan timbal balik dan identitas (Santrock, 2012:45).

\section{Tahap Operasional Formal (Umur 11/12-18)}

1. Perkembangan penalaran abstrak (Jarvis, 2011:111). Anak sudah bisa memikirkan tentang hal-hal yang tidak berwujud. Misalnya, sudah bisa menganalisa contoh kasus.

2. Mencapai kemampuan untuk berfikir dan berbeda dengan fakta / realitas. Anak dalam tahap ini sudah bisa berimajinasi. Mempunyai daya khayal dan angan-angan yang tinggi. Hal ini akan berubah ketika remaja mulai memasuki dunia dewasa, bila mereka mulai menyadari keterbatasan baik yang ada pada dirinya, maupun yang berhubungan dengan realitas di lingkungan hidupnya.

3. Bekerja secara efektif dan sistematis. Anak sudah bisa menyusun sesuatu secara berurutan. Mereka sudah bisa melakukan penggabungan.

4. Menganalis secara kombinasi. Pada masa ini remaja sudah bisa memahami adanya bermacam-macam aspek pada suatu persoalan yang dapat diselesaikan seketika, sekaligus. Tidak lagi satu persatu seperti yang biasa dilakukan anak-anak pada masa konkrit operasional. Dari ini terlihat pula bahwa perkembangan kognitif pada masa formal-operasional mencapai tingkatan tertinggi pada keseimbangan dalam relasinya dengan lingkungan.

5. Remaja memasuki dunianya dengan segala macam kemungkinan dan kebebasan untuk memikirkan sendiri. Seiring dengan ini muncul kembali sifat egosentrisme.

6. Dilihat dari faktor biologis, tahapan ini muncul saat pubertas (saat terjadi berbagai perubahan besar lainnya), menandai masuknya ke dunia dewasa secara fisiologis, kognitif, penalaran moral, perkembangan psikoseksual, dan perkembangan sosial. Beberapa orang tidak sepenuhnya mencapai perkembangan sampai tahap ini, sehingga ia 
tidak mempunyai keterampilan berpikir sebagai seorang dewasa dan tetap menggunakan penalaran dari tahap operasional konkrit. Dapat dikemukakan bahwa pada rentang usia ini mereka telah mencapai kemampuan berpikir sistematis terhadap hal-hal abstrak, hipotesis dan berpikir alternatif (Santrock, 2012:45).

Menurut Feldmeier, secara kognitif anak mulai bicara dan mengambil alih perbendaharaan kata orang dewasa, meskipun belum memahaminya pada usia 2-4 / 5 tahun. Perlahan pada usia 4 / 5-7 tahun anak mulai berpikir intuitif. Lingkungan mereka mulai diperluas, lebih dari lingkungan keluarga dan perkembangan ego mulai berkenaan dengan dunia dan dirinya sendiri. Pada usia 6-12 tahun anak mulai terobsesi dengan peraturanperaturan yang ada di sekitarnya (Feldmeier, 2007; 98). Piaget meyakini, bahwa semua manusia melalui keempat tahap tersebut di atas, meskipun mungkin setiap tahap dilalui dalam usia berbeda. Setiap tahap dimasuki ketika otak manusia sudah cukup matang untuk memungkinkan logika jenis baru atau operasi (Jarvis, 2011:148). Piaget tidak melihat intelegensi sebagai suatu yang dapat didefinisikan secara kuantitatif, serta mengemukakan bahwa kemampuan berpikir atau kekuatan mental anak yang berbeda usia akan berbeda pula secara kualitatif (Azwar, 2011:35). Pada pemikiran formal, ada tiga unsur yaitu pemikiran deduktif, induktif dan abstrkatif.

\section{Analisis dan Implikasi Teori Perkembangan Kognitif}

Anak sebagai ciptaan Allah (imago Dei) yang berkembang dalam aspek kognitif (kemampuan nalarnya). Anak bukan orang dewasa kecil. Tahapan perkembangan kognitif anak perlu mendapat perhatian. Tuhan menggunakan berbagai aspek untuk membentuk anak. Misalnya, melalui permainan, alat peraga, aktivitas kelompok, imaginasi dan lainnya. Dalam Matius 19:13-15 diketengahkan bahwa Yesus melayani anak. Paulus dalam Efesus 6:4 berpesan bahwa ayah membesarkan anak dengan ajaran dan nasehat Tuhan.

Tidak sedikit orang dewasa berpikir seperti anak: pra-operasional dan operasional konkrit, tidak mampu berpkir operasional formal (abstrak, hipotesis). Anak dapat "memberkati" orang dewasa dengan pola pikir yang polos, berdasarkan fakta, keterbatasan, dan kebergantungan kepada otoritas - "menjadi seperti anak kecil" dan "tidak meremehkan iman anak" (Mat. 18:3,4,5,10). Pengajaran tidak boleh hanya melalui pemberitahuan, namun melalui mengalami. Orang dewasa harus berubah (1 Kor. 13:11).

Menurut (Wilhoit dan Dettone, 1995: 58-59), Kristen perlu mengevaluasi dan memodifikasi teori Piaget dalam kuasa terang Firman Allah dan harus dikuasai / dipimpin oleh Roh Kudus untuk efektifitas pendidikan Kristen. Walaupun, Piaget tidak membuat klaim 
bagi pengikut Kristus, wawasannya / pengertiannya bisa mengingatkan pendidik Kristen akan prinsip-prinsip dasar Alkitab. Tidak semua prinsip-prinsip teori Piaget sesuai dengan Alkitab dan tidak semua prinsip-prinsip teori Piaget bertentangan dengan Alkitab. Salah satu sumbangsih positif yang dapat dimanfaatkan dari teori Piaget adalah bahwa bahasa dan cara berpikir anak berbeda dengan bahasa dan cara berfikir dewasa. Itulah sebabnya dalam mengajar, guru hendaknya menggunakan bahasa yang sesuai dengan cara berpikir anak (dalam gereja ada pemisahan antara pra-remaja dengan remaja).

Hal yang berbeda adalah bahwa tujuan pembelajaran sekuler berbeda dengan pembelajaran orang Kristen. Tujuan pembelajaran sekuler adalah pemuliaan diri sendiri, bertumbuh dan berkembang untuk diri sendiri. Sedangkan, bagi orang Kristen tujuan dari pertumbuhan atau perkembangan adalah untuk memuliakan Tuhan dan menjadi sama dengan-Nya. Tujuan pendidik Kristen tidak hanya membuat peserta didik menjadi pintar melainkan disertai dengan takut akan Tuhan (perjumpaan peserta didik secara pribadi dengan Tuhan). Menurut Perry G. Dowans (1994: 90) dalam bukunya, menyatakan bahwa teologi memberitahu isi yang perlu diajarkan, namun psikologi membantu guru mengetahui kapan dan bagaimana mereka mengajar.

Ada beberapa inspirasi yang diperoleh dari Jean Piaget sebagai Psikolog Perkembangan Kognitif, antara lain:

1. Piaget menolong guru untuk melihat bahwa tujuan dari pendidikan adalah perkembangan / pertumbuhan. Bagi orang Kristen, tujuan akhir dari perkembangan manusia adalah agar manusia memuliakan Tuhan dengan cara menjadi serupa dengan Yesus Kristus dalam segala aspek kehidupan. Tugas yang sulit dari pendidik Kristen adalah membantu perkembangan peserta didik menjadi sama seperti Kristus. Seharusnya pendidik Kristen tidak hanya transfer pengetahuan, melainkan menjadi pendidik karakter juga.

2. Piaget menolong guru untuk melihat bahwa pengetahuan adalah sebuah aktivitas sosial. Manusia bertumbuh sebagaimana mereka berinteraksi dengan orang lain. Hal ini dapat dilihat di dalam jemaat mula-mula dimana mereka belajar Alkitab bersamasama, sehingga mereka dapat bertumbuh secara rohani (bnd. Kis. 2: 41-47). Ceramah yang baik dan khotbah pengajaran yang kuat mungkin dapat digunakan sebagai stimulus penting untuk pendidikan, namun Piaget mengingatkan bahwa orang harus berinteraksi dengan orang lain agar mengalami pertumbuhan.

3. Piaget membantu guru untuk melihat bahwa belajar adalah sebuah proses ketidakseimbangan dan menyeimbangkan. Manusia tumbuh seperti yang ia bergulat 
dengan isu-isu dan masalah kehidupan dalam terang Firman Tuhan. Hidup ini penuh frustrasi dan tantangan. Manusia dipengaruhi oleh dosa dalam setiap tahap pertumbuhan rohani. Manusia akan selalu menghadapi ketegangan antara cara ia hidup dan bagaimana ia harus hidup. Kabar baik dari Injil harus selalu menjadi jawaban untuk berita buruk dari situasi manusia. Tujuan dari pengetahuan, bahkan pengetahuan tentang Alkitab, adalah bahwa hal itu menjadi alat untuk membantu untuk menyelesaikan dilema terdalam manusia (Wilhoit dan Dettone, 1995: 59).

4. Teori ini mengingatkan agar proses belajar yang dialami seorang anak sesuai dengan tahap perkembangan kognitif, tahap kognitif mengontrol apa yang anak dapat pelajari (Dowans, 1994: 90). Hal ini telah dipraktikkan oleh Tuhan Yesus, dimana dalam mendekati orang Ia mempergunakan cara yang berbeda-beda (sikap Yesus dengan anak-anak; Mat. 19:13-15, berbeda dengan sikap Yesus dalam mendekati wanita Samaria; Yoh. 4:1-26).

5. Orangtua sebagai anggota jemaat hendaknya kreatif dalam memberikan informasi baru kepada anak, khususnya tentang PAK (Bnd. Ul. 6:4-9). Melalui cerita, alat peraga dan permainan, dan lain-lain. Untuk mengajar anak angka-angka, harus diperlihatkan benda-benda yang dapat dihitung.

6. Karena cara berpikir anak itu berbeda-beda dan kurang logis dibandingkan dengan orang dewasa, maka pengajar harus dapat mengerti cara berpikir anak, bukan sebaliknya anak yang beradaptasi dengan guru.

7. Sebaiknya pengajaran tidak hanya melalui pemberitahuan namun diikuti dengan proses mengalami. Dengan kata lain, pemberitahuan dan mengalami dilakukan secara seimbang.

8. Pentingnya proses penyeimbangan (ekuilibrasi) demi pengembangan pengetahuan, sekaligus menjaga stabilitas mental.

Pembelajaran ialah suatu proses yang dilakukan oleh individu untuk memperoleh suatu perubahan perilaku yang baru secara keseluruhan, sebagai hasil dari pengalaman individu itu sendiri dalam interaksi dengan lingkungannya (Surya, 200: 7). Perubahan sebagai hasil belajar ditandai dengan ciri-ciri sebagai berikut: 1) Perubahan yang disadari. b) Perubahan yang bersifat kontinue dan fungsional. c) Perubahan yang bersifat positif dan aktif. d) Perubahan yang bersifat relatif permanen dan bukan yang bersifat temporer, dan bukan karena proses kematangan, pertumbuhan dan perkembangan. 2) Perubahan yang bertujuan dan terarah. a) Hasil belajar ditandai dengan perubahan seluruh aspek pribadi. b) Belajar merupakan suatu proses yang disengaja. c) Belajar terjadi karena ada dorongan dan tujuan 
yang ingin dicapai. d) Belajar merupakan suatu bentuk pengalaman yang dibentuk secara sengaja, sistematis dan terarah.

Jamaris mengemukakan bahwa penerapan teori perkembangan kognitif Piaget dalam proses pembelajaran dilaksanakan dengan memberi kesempatan pada anak agar dapat belajar secara aktif dengan jalan menyajikan berbagai tantangan melalui berbagai masalah yang mendorong kegiatan peserta didik secara aktif (2003:151). Berdasarkan kriteria aktifitas fisik dalam penerapan teori Piaget, maka dapat dikemukakan bahwa anak harus aktif terlibat dalam mengkonstruk pengetahuan melalui objek-objek yang nyata, yang dapat dieksplorasi anak secara langsung. Guru berperan sebagai fasilitator dan penuntun agar anak sampai pada pengetahuan yang diharapkan dapat dicapai melalui pertanyaan prediktif. Selain itu guru juga berperan sebagai perancang kegiatan yang memungkinkan anak mengembangkan pengetahuannya (Ginting, 2018; 165).

Hal senada dikemukakan Murniarti bahwa ketika ingin menerapkan teori perkembangan kognitif Piaget untuk pendidikan anak harus mengacu pada; Pertama, gunakan pendekatan konstruktivis. Kedua, Fasilitasi mereka untuk belajar. Ketiga, Pertimbangkan pengetahuan dan tingkat pemikiran anak. Keempat, gunakan penilaian terus menerus. Kelima, Tingkatkan kemampuan intelektual murid. Keenam, Jadikan ruang kelas menjadi ruang eksplorasi dan penemuan (Murniarti, 2020: 1011). Demikian juga dengan Ichsan menandaskan, implikasi teori perkembangan kognitif menurut Ichsan (2009:1) antara lain; tekanan pada keaktifan peserta didik, melibatkan partisipasi aktif peserta didik, belajar aktif, dan guru berperan sebagai fasilitator pengetahuan, mampu memberikan semangat belajar, membina dan mengarahkan peserta didik.

Sebagai perbandingan, menurut Dahar (Dahar, 1989) ada beberapa poin penting yang dapat diaplikasikan dalam pembelajaran sains; 1) Jenis pengetahuan bagi anak: a) Pengetahuan fisika, dan logiko matematik. b) Pengetahuan sosial - transmisi sosial. 2) Siklus belajar: a) Deskriptif. b) Empiris induktif. c) Hipesis-deduktif. 3) Cara membangun pengetahuan anak: a) Konstruktivisme. Prinsip konstruktivistik: Alat peraga, kegiatan menarik, pertanyaan-masalah, interaksi diantara anak, tekankan berpikir, anjurkan anak berpikir dengan caranya dan reinforcement.

Dengan memahami perkembangan anak secara kognitif, sangat diharapkan para guru di lingkungan Pendidikan Kristen mampu mengaplikasikannya dalam pengajaran, penyusunan kurikulum, pendekatan dan juga bagaimana memperlakukan anak. Melalui pengetahuan dan pemahaman perkembangan secara kognitif para guru harus menyadari bahwa posisi mereka penting dalam perkembangan anak, maka harus dilandasi dengan 
keteladanan hidup. Guru di lingkungan Pendidikan Kristen perlu untuk menginsafi bahwa anak-anak sedang berada di posisi keemasan mereka (golden age). Disebut golden age karena pada masa ini perkembangan anak pada segala aspek sangat pesat dibandingkan dengan masa-masa berikutnya, seperti yang dikemukakan Montessori (Sujiono, 2009:54). Anak-anak sedang mengeksplorasi, mengimitasi, dan menginternalisasi lingkungan di mana mereka berada. Dalam konteks ini anak-anak perlu mendukung anak, memberi perhatian dan mengajar dengan kepribadian yang luhur. Berkaitan dengan pemanfaatan metode mengajar, maka seorang guru di Pendidikan Kristen harus juga memperhatikan perkembangan kognitif mereka. Melaluinya mereka secara kreatif dan inovatif dalam menerapkan metode dan media pembelajaran sehingga anak-anak lebih mudah memahami apa yang diajarkan.

Akhirnya, Piaget menolong untuk melihat bahwa tujuan dari pendidikan adalah perkembangan atau pertumbuhan. Piaget menolong untuk melihat bahwa pengetahuan adalah sebuah aktivitas sosial. Piaget telah memberikan sumbangan yang besar dalam dunia pendidikan dan hasil-hasil karya piaget tentang perkembangan kognitif yang ditulis dalam bentuk lebih dari 50 buku . Piaget memberi warna baru dalam proses belajar dimana guru perlu mengatur stimulus yang diterima dan menyesuaikannya dengan struktur kognitif yang sudah dimiliki dan terbentuk di dalam pikiran seseorang berdasarkan pemahaman dan pengalaman-pengalaman sebelumnya. Perlunya guru mengembangkan sikap ekuilibrasi .

Di samping itu, Piaget, menginspirasi perlunya memberi peluang agar peserta didik belajar sesuai dengan peringkat perkembangannya (karena cara berfikir anak berbeda dengan cara berfikir orang dewasa). Misalnya, di dalam gereja di buat pemisahan antara pra-remaja dengan remaja, dan lain-lain. Bahasa anak berbeda dengan orang dewasa. Oleh karena itu guru hendaknya mengajar dengan menggunakan bahasa yang sesuai dengan cara berfikir anak. Bahan yang harus dipelajari anak hendaknya dirasakan baru tetapi tidak asing. Teori Piaget membahas kognitif atau intelektual. Perkembangan intelektual erat hubungannya dengan belajar, sehingga perkembangan intelektual ini dapat dijadikan landasan untuk memahami belajar. Peserta didik akan belajar lebih baik apabila dapat menghadapi lingkungan dengan baik. Pengajar harus membantu agar dapat berinteraksi dengan lingkungan dengan sebaik-baiknya. Bisa melalui ruang yang memadai, permainan, alat peraga, dan lain-lain. Penerimaan terhadap perbedaan individu dalam kemajuan perkembangan, teori Piaget mengasumsikan bahwa seluruh anak berkembang melalui urutan perkembangan yang sama namun mereka memperolehnya dengan kecepatan yang berbeda.

Piaget mengemukakan dalam penelitiannya terhadap struktur, isi dan fungsi bahwa ada lima faktor yang menunjang perkembangan kognitif yaitu kedewasaan, pengalaman fisik, 
pengalaman logika-matematis, transmisi sosial dam proses keseimbangan atau proses pengaturan diri (Philips, 1981). Biarlah faktor-faktor ini menjadi pusat perhatian para guru di lingkungan Pendidikan Kristen agar tercipta pembelajaran yang bermakna, kontekstual, menjawab kebutuhan, relevan, efektif dan efisien.

\section{Kesimpulan Dan Saran}

Jean Piaget adalah tokoh besar abadi dalam Psikologi Perkembangan, khususnya perkembangan kognitif. Menurut Piaget perkembangan kognitif anak dapat dibagi ke dalam empat periode utama yaitu; tahap sensori motor (0-2 tahun); tahap preoperasional ( $2 \mathrm{~s} / \mathrm{d} 7$ / 8 tahun); tahap operasional konkrit (7 atau 8-11 atau 12 tahun); dan tahap operasional formal (umur $11 / 12-18$ ).

Salah satu sumbangsih positif yang dapat dipergunakan dalam tugas Pendidikan Kristen adalah bahwa bahasa dan cara berpikir anak-anak berbeda dengan bahasa dan cara berpikir orang dewasa. Selain itu, Piaget mengemukakan bahwa orang bertumbuh saat mereka berinteraksi dengan orang di sekitar mereka. Kognisi seseorang berkembang bukan karena menerima pengetahuan dari luar secara pasif, namun orang tersebut secara aktif mengkonstruksi pengetahuannya. Pendidikan bukan hanya sesuatu yang memberikan kepada orang lain (transfer pengetahuan), seperti guru memberikan pendidikan kepada peserta didik. Namun, pendidikan sejati adalah reflektif interaksi antara peserta didik dan lingkungan atau pengetahuan adalah sebuah aktivitas sosial (seseorang bertumbuh sebagaimana ia berinteraksi dengan orang lain).

Akhirnya, mengetahui dan memahami perkembangan anak secara kognitif sangat signifikan agar pembelajaran dalam konteks Pendidikan Kristen disajikan sesuai target dan dapat mencapai tujuan. Kurikulum yang dirancang dan dilaksanakan harus disesuaikan dengan tugas, kebutuhan, peran dan perkembangan peserta didik.

Untuk penelitian selanjutnya diharapkan untuk melaksanakan studi lapangan (apakah dengan metode kualitatif, kuantitatif, kombinasi, dan lain-lain) untuk mengkaji penerapan teori perkembangan kognitif Jean Piaget di Taman Kanak-Kanak (TK) atau di Pendidikan Anak Usia Dini (PAUD); korelasi antara pemahaman tahap-tahap perkembangan kognitif dengan efektifitas pembelajaran di Taman Kanak-Kanak (TK) atau Pendidikan Anak Usia Dini (PAUD). Melalui penelitian tentang Analisis Teori Perkembangan Kognitif Piaget ini diharapkan semakin banyak guru di lingkungan Pendidikan Kristen yang tertolong dalam merencanakan, melaksanakan dan mengevaluasi pembelajaran yang relevan, bermakna, efektif, efisien dan menjawab kebutuhan tugas dan peran anak; juga sebagai usaha 
penyadaran bagi guru agar mampu menjadikan kehidupannya sebagai arena untuk memuliakan Allah. Soli Deo Gloria.

\section{Daftar Pustaka}

Budiningsih, Asri C. Belajar dan Pembelajaran. Jakarta: Rineka Cipta, 2005.

C. George Boeree. Sejarah Psikologi. Yogyakarta: Prismasophi, 2007.

Dahar, Ratna W. Teori-Teori Belajar Anak. Jakarta: Erlangga, 1989.

Diane, E. Papalia, at.al, Psikologi Perkembangan. Jakarta: Kencana, 2008.

Dowans, G Perry. Teaching For Spritual Growth. America: Zondervan Publishing House, 1994.

Feldmeier, Peter. The Developing Christian: Spritual GrowthThrough the Life Cycle. New York: Paulis Press, 2007.

Ginting, Meta. Membangun Pengetahuan Anak Usia Dini Melalui Permainan Konstruktif Berdasarkan Perspektif Teori Piaget. https://www.researchgate.net/publication/334601262. Jurnal Caksana Pendidikan Anak Usia Dini, Volume 1 No 2 Desember 2018.

Ichsan, Mempertimbangkan Teori Perkembangan Kognitif Jean Piaget Dalam Pembelajaran PAI. https://jurnal.albidayah.id/index.php/home/article/view/4. Jurnal Pendidikan Dasar Islam, AL-BIDAYAH, Vol. 1 No. 1 (2009). https://doi.org/10.14421/albidayah.v1i1.4.

Ibda, Fatimah, Perkembangan Kognitif: Teori Jean Piaget.

https://jurnal.ar-raniry.ac.id/index.php/intel/article/view/197. Jurnal Intelektualita, Vol. 3, No. 1 (2015).

Jr. Philips, John L. The Origin of Intellect: Piaget's Theory. USA: W.H. Freeman and Company.

Ladidius Naisaban. Para Psikologis Terkemukaka Dunia: Riwayat Hidup, Pokok Pikiran dan Karyanya. Jakarta: Grasindo, 2006.

Matt Jarvis, Teori-Teori Psikologi. Bandung: Nusa Media, 2011.

Moleong, J. Lexy. Metode Penelitian Kulaitatif. Bandung: Remaja Rosdakarya, 2011.

Murniarti Erni, Teori Perkembangan Kognitif Piaget, Perkembangan Psikososial dan Teori Moral Kohlberg. Jakarta: UKI, 2020.

Nainggolan, Mandimpu Alon. Blended Learning Sebagai Model Pembelajaran Pendidikan Agama Kristen Di Pendidikan Tinggi Pada Masa Dan Pasca Pandemi Covid-19. https://ejournal-iakn manado.ac.id/index.php/didaskalia/article/view. Didaskalia: 
Jurnal Pendidikan Agama Kristen, Vol. 1 No. 2 (2020).

Paul Suparno, Perkembangan Kognitif Jean Piaget. Yogyakarta: Kanisius, 2006.

Piaget, Jean \& Inhelder, Barbel. Psikologi Anak. Yogyakarta: Pustaka Belajar, 1969.

Santrock, Joh. W. Life Spant Development. Jakarta: Erlangga, 2012.

Singgih D. Gunarsa. Dasar Dan Teori Perkembangan Anak. Jakarta: BPK Gunung Mulia, 2006.

Stonehouse, Chaterine. Joining Children on The Spiritual Journey. Baker Books, 1998.

Sujiono, Yuliani Nurani. Konsep Dasar PAUD. Jakarta: PT Indeks, 2011.

Surya, Mohamad. Psikologi Pembelajaran dan Pengajaran. Bandung: Pustaka Bani Qurasy, 2004.

Wilhoit, C James \& Dettoni, M John. Nurture That Is Christian. America: Zondervan Publishing House, 1995.

Wina Sanjaya. Strategi Pembelajaran Berorientasi Standar Proses Pendidikan. Jakarta: Prenada Media Group, 2010. 